\title{
Matusekommetest Kirde-Eestis 19. sajandil ja 20. sajandi algul ${ }^{1}$
}

Merike Lang

\begin{abstract}
Teesid
Artikkel käsitleb surmaga seotud uskumusi ja kombeid 19. sajandi lõpul ja 20. sajandi algul. Alguses vaadeldakse suhtumist surevasse haigesse ja sellega seonduvaid talitusi. Nii surija kui suretajate häälestamine eelseisvateks muutusteks moodustab matusekombestiku esimese perioodi. Surm kui bioloogiline muutus alustab matuste teist perioodi. Siia kuuluvad laiba pesemine, rõivastamine ja öine valvamine. Sisuliselt on tegemist surnuga suhtlemisega, tema lepitamisega elavatega.

Kõige tihedam tavandi osa algab kolmanda perioodiga - surnu kodust ärasaatmisega. Selle perioodi riitused aitavad lahkunut kinnistada teise maailma, kuid samal ajal irrutavad teda elavatest. Neljanda perioodi moodustavad peied, mis tähistavad surnu jõudmist uude sotsiaalsesse staatusse. Kõikide eelnevate perioodide eduka läbiviimise järel ei peaks surnu enam ellujääjatele ohtu kujutama. Rahvalikud uskumused on taandunud 20. saj jooksul. Eelkõige kaovad esimese ja teise perioodi taiad, kolmandal ja neljandal perioodil saab valitsevaks ametlik kiriklik riitus.
\end{abstract}

Märksõnad: ended, hingevaakumine, matusekombestik, ohverdamine, surma nimed, peied, siirderiitused.

Surmaga seotud uskumused ja kombed moodustavad meie rahvakultuuris omaette teema. Iga ajajärk on siia ladestanud oma arusaamad ja tavad, mis on kas varasematega põimunud või eelmised välja tõrjunud. Selle tulemusel on kujunenud keerukas rituaalide kogum, mille esialgset tagapõhja on raske, sageli võimatu lahti mõtestada. Kuna matusekombed on üsna konservatiivse iseloomuga, pole nad tänaste uurijate õnneks oma muistset vormi veel täielikult minetanud. Iseenesest mõista on sisuline külg olnud kiirem kaduma ning seega täidetakse paljusid tavasid vaid seetõttu, et nii on varem tehtud ja nii näeb ette vana traditsioon.

Seni on matusekommetele pööratud põhjendamatult vähe tähelepanu. Arheoloogid on uurinud muinasaegseid matuseid, tunduvalt vähem on aga huvi tuntud 13.-18. sajandi külakalmete vastu. Sel teemal on valminud vaid kaks ülevaatlikku diplomitööd: 1974. aastal Ain Lavi Külakalmete uurimisest Põhja-Eestis ja 1983. aastal Heiki Valgu Kagu-Eesti keskaegsed külakalmed. Suulise rahvatraditsiooni sihikindla kogumise käigus laekunud materjalidele tuginedes fondid H, E, ERM, E StK, ERA ja EKS Eesti Kirjandusmuuseumi 


\section{Merike Lang}

Eesti Rahvaluule Arhiivis - valmis 1939. aastal Amanda Raadla seminaritöö Eesti matusekommete ülevaade. 1923.-1924. aastal teostas Setumaal iseseisvaid vaatlusi Ilmari Manninen, kes seejärel avaldas vastavasisulise artikli Eesti Kirjanduses (Manninen 1924b: 1019). Tema koostatud on ka põhjalik matusekombeid käsitlev küsitluskava (Manninen 1924a: 173-176). Korrespondentidele seda vististi ei saadetudki, sest vastuseid sellele Eesti Rahva Muuseumis pole.

Võrreldes varasemaga on sõjajärgsetel aastatel olnud materjali juurdekasv väike. See on koondunud põhiliselt Eesti Keele Instituuti (kogud KKI, ${ }^{2}$ KKI MT, ÜS) ning Emakeele Seltsi (kogu KT). Eesti Rahva Muuseumi teadurid on matuste kohta küsitlenud vaid seoses tavanditoitudega ning puutöönduse (puusärgi valmistamine) ja leinariietusega (kogud KV ja EA).

Matusekombeid käsitlevaid iseseisvaid uurimusi leiame vaid üliõpilastelt. Nii valmis 1970. aastal Tartu Ülikooli kirjanduse ja rahvaluule kateedri juures Eha Alliku diplomitöö Eesti surmaended, 1971. aastal Danute Sirijos-Giraite kursusetöö Surnutekultuse ühiseid jooni eesti, liivi, läti ja leedu rahvaluules ning mütoloogias ning 1978. aastal Eha Viluoja diplomitöö Surmakujutelmast eesti rahvauskumustes. Kodukäija tõrje. NSV Liidu ajaloo kateedri juures valmis 1981. aastal Merike Langi diplomitöö Endisaegsed matusekombed Ida-Eestis. ${ }^{3}$ Viimasele toetub ka käesolev artikkel, mis hõlmab endiste Jõhvi, Iisaku ja Vaivara kihelkondade materjale. Eespool nimetatud teadusasutustest oli selleks võimalik sedeldada 275 teksti, millest Jõhvi kihelkonna notiitsid moodustavad 51\%, Iisaku 25\% ja Vaivara 24\%. Paraku ei kajasta toodud arvud materjali sisulist väärtust. Suur osa sellest on vaid sõnaseletused. Pikematest kirjeldustest võiks eraldi nimetada 1944. aastal Jõhvi kihelkonnas kirja pandud murdeteksti (KT 80, 66-87), mis on ka publitseeritud (Ahven 1957). Et korvata andmete nappust, käis artikli autor 1980. aastal täiendavalt välitöödel endistes Iisaku ja Vaivara kihelkonnas.

Tutvustamaks lähemalt matusekombestikku, mis 19. ja 20. sajandi vahetusel oli veel käibel, kuid nüüdseks paljuski hääbunud, on vastav materjal esitatud eelkõige tavandi deskriptiivse ülevaatena. Käsitlus algab juba inimese haiguse perioodist, kuna mitmetest sel ajal toimetatud taigadest ja ennetest usuti olenevat nii surnu kui ka elavate hilisem käekäik ning seega liitusid need lahutamatult matusekombestikku. Vaatlus lõpeb peietega, 
jättes välja järgneva hingedeaja, kuna see on seotud pigemini kõigi esivanemate, mitte ühe konkreetse viimati surnud perekonnaliikme mälestamisega ning kujutab seega iseseisvat uurimisteemat.

\section{Haigus ja surm}

Haiguse raskenedes ning peatse surma kartusel kutsuti naabrid või sõbrad haiget suretama, sest inimest ei võinud üksinda surra lasta. Kes esmakordselt põdeja juurde tuli, pani tähele, kas see liigutas tervituseks paremat või vasakut kätt. Kuna pahem pool on alati halba tähendanud, siis usuti, et selle käe liigutamisel tuleb kindlasti surm, parem käsi aga andis veel lootust tervenemisele. Võrdlevalt jälgiti kätt ja jalga: levinud oli usk, et käe liigutamine tähendab surma, jalg aga elu (H II 36, 438/9 (20) < Vaivara khk, Vaivara v, Türsamäe k - Johannes Sorro (1893); ERA II 268, 567 (5) < Jõhvi khk, Kohtla v, Kohtla k, Metsa t - Endel Mets < Salme Mets, s 1894 (1939)).

Suretamisel vajas haige tähelepanu, teda tuli julgustada, tema soovid tuli ära kuulata ja need ka kindlasti täita, sest muidu võis ta hiljem hakata koju käima ja lubadust taga nõudma.

Pikaldane elu ja surma vahel vaakumine oli koormaks nii haigele kui ka omastele. Eelkõige oli probleem nõidade ja tarkadega, sest

[---] vanapagan ei taha, et nõidujaid ja tarku vähä jääb maailma ja senepera tieb surma koledast, et moni haleda südämäga võtab kunsti omale ja hakkab seda edasi tegema. Muidu sureb tark kõigega (ERA II 268, 572 (24) < Jõhvi khk, Kohtla v, Kohtla k, Metsa t - Endel Mets < Salme Mets, s 1894 (1939).

Ent tavalinegi inimene võis kaua vaevelda, kui polnud täidetud rida nõudmisi. Varasematest uurimustest ja publikatsioonidest on teada, et hingeheitmise kergendamiseks tõsteti haige põrandale laotud õlgedele (Luce 1827: 101; Boecler \& Kreutzwald 1854: 67; Kreutzwald 1953: 68; Wiedemann 1876: 309; Jung 1879: 109; Waronen 1898: 57; Vulfson 1908: 61; Grünthal 1912: 344; Reiman 1915: 140; Raadla 1939: 6-7; Tampere 1960: 207). Kirde-Eestist pärinevad notiitsid sellest ei räägi (võib-olla oma uuemaaegse päritolu tõttu). Ka vadjala- 


\section{Merike Lang}

sed lasid inimesel surra seal, kus ta haigena lamas (Ariste 1974: $151,158,166,176,179)$. Küll aga teati, et surija voodi ei tohtinud seista lae aampalkidega risti, sest nii moodustus haige silmade kohale nõiamärgina rist ja hing ei saanud välja lennata (H II 8, 117 (22) < Jõhvi khk, Toila v, Päite k - Paulus Paurmann (1889); H III 1, 545 (10) < Iisaku khk, Kauksi k - Emilie Ellert (1889); ERA II 125, $49(20)$ < Jõhvi khk, Illuka v, Kurtna as, Linna t < Vaivara khk Mart Tarum, ERA stipendiaat < Miina Tarum, s 1876 (1936)). Samal põhjusel nõuti ka uste ja akende avamist (ERA II 268, 171 (26) < Iisaku khk, Tärivere v, Lõpe k < Jõhvi khk, Kurtna v - Erich Luht < Indrik Aunap, s 1849 (1939)).

Hinge lahkumisega saabus surm, mille kohta öeldi:

[---] jo Jumal korjas sene, see magab viimist und, see magab mulla peremees, selle hing on jo välles, see on juba otas, tema on juba siit maailmast kadunud, tema on selle maailma murest ja vaevast päästetud, tema on selle maailma maha jätnud... (H II 37, 150 (1) < Vaivara khk - Hermann Hendel (1892)).

Tämä läks enguselle, ehk jälle: puhkab viimast und. See inimene pidi pulmad: Kui noored inimesed surevad. - Poig ehk tüttär võeti keriku võla eest... (ÜS - Jõhvi khk).

Isikustatud surma nimetati Liiva Annuseks (Jõhvi, Iisaku, Vaivara khk), Liiva Peetriks (Iisaku, Vaivara khk), Surma Peetriks (Iisaku khk), Toone Toomaseks (Jõhvi, Vaivara khk), Kalmu Kaarliks (Jõhvi, Vaivara khk), Mulla Peetriks (Jõhvi khk), Mulla Madiseks (Jõhvi, Iisaku khk) või Mulla Matsiks (Jõhvi khk). Oskar Looritsa järgi on sellised surmavaimu tähistavad nimetused tulnud Eestis tarvitusele ajaloolisel ajal saksa mõjudel (Loorits 1932c: 93; 1932d: 67; 1949: 453).

Huvitavaid tähelepanekuid on tehtud kõige "parema" ja sagedasema suremise aja kohta.

Pattune sureb pilve ilmaga ja õnnis sureb selge ilmaga (ERA II 199, 77/8 (10) < Jõhvi khk, Kohtla v, Kohtla k, Metsa t Endel Mets < Salme Mets, s 1894 (1938)).

Õnnis sureb hommiku. Kes sünnib päiväl ja sureb, senel ei ole ka suurt paha, aga ükski ristiinimene ei sünni ega sure üäsä... (ERA II 268, 573 (29) < Jõhvi khk, Kohtla v, Kohtla k, Metsa t - Endel Mets < Salme Mets, s 1894 (1939)). 
Kahtlemata lähtuvad need seisukohad kristlikust mõtteviisist. Hoopis looduslähedasem ja loodusest analoogiaid leidev on arusaam, et kõige suurema suremuse ajaks on sügiskuud ning jaanuar ja veebruar (Iisaku, 1980).

\section{Surnu pesemine ja rõivastamine}

Suremise hetkest alates tuli lahkunu sugulastel ja tuttavatel hakata järgima mitmeid nõudeid, mis tagaksid koolnule nii oma osa saamise kui ka kaitstuse ning sugulastele endile hilisema rahuliku põlve.

Esmaseks nõudeks oli surnu silmade ja suu korralik sulgemine, sest muidu jõudis ta endale järgneja välja vaadata. Suu kaudu võis aga vanakurat laiba sisse pugeda. Et vältida koolnu kuju peegeldust ja sellega surma jäädvustumist, tuli matusemajas peegel kinni katta ja omaksed ei tohtinud kanda läikivaid ehteid (H II 8, 117 (22) < Jõhvi khk, Toila v, Päite k - Paulus Paurmann (1889); ERA II 268, 575 (36) < Jõhvi khk, Kohtla v, Kohtla k, Metsa t - Endel Mets < Salme Mets, s 1894 (1939); ERA I 4, 169 (1) < Iisaku khk, Iisaku v, Uhe k - Tallinna Posti ebausu võistlus < Eduard Kreenmann (1932); KT 80, 68 < Jõhvi khk (1944); Iisaku, Vaivara, 1980).

Koolnud maise eksistentsi lõpetamiseks oli vaja teda korralikult pesta. See toimus kas põrandale laotatud õlgedel (KT 80, $67<$ Jõhvi khk (1944); Iisaku, 1980), pesukünas (ERA II 268, 575 (38) < Jõhvi khk, Kohtla v, Kohtla k, Metsa t - Endel Mets < Salme Mets, s 1894 (1939)), mis on A. Raadla järgi valdavalt Lääne-Eestile omane tava (Raadla 1939: 18), kahel pingil (Iisaku, 1980) või toolil, millele surnu istuma pandi (Iisaku, 1980). Samasugune komme on tuntud ka liivlastel (Loorits 1932a: 181). Pesemiseks kasutati alati sooja vett, vihta ja seepi. Surnu näo ja käte piiritusega puhastamine hakkas levima alles 20. sajandi alguses (Iisaku, Vaivara, 1980). Kuna nimetatud asjad puutusid surnu ja tema kahjuliku väega otseselt kokku, kehtisid nende edasise kasutamise juures teatud piirangud.

Surnu pessu vessi saab põhja poole tua nurka ala maha kalatud. Ja siis kuulatud, kus pool külges tuule vingumist kuulda on, kui seda kuulukse, kus pool on, siis sealpool saab surema (E $282(64)<$ Jõhvi khk - J. Seland (1893)). 


\section{Merike Lang}

Surnupesemise vett ei tohtinud puu peale valada, puu pidi ära kuivama. Pidi palja maa peale valama (KKI 20, 167/8 (46) < Iisaku khk, Koldemäe k - Loreida Raudsep, Helgi Kihno < Rosalie Leitsmann, 79 a (1955)).

Surnupesemise seebi kasutamise kohta puuduvad vaadeldavast piirkonnast varasemad andmed. Välitöödel küsitletud mäletasid vaid, et seda enam ei tarvitatud. Samal ajal aga näiteks Võrumaal kasutati seda arstirohuna (Manninen 1924b: 12; Lang 1981: 32) ning on ka andmeid seebist kui hauapanusest (Hupel 1777: 155; Boecler \& Kreutzwald 1854: 68; Kreutzwald 1953: 68; Wiedemann 1876: 309; Jung 1879: 112; Reiman 1915: 143; Raadla 1939: 21 ja 34). Hauapanuseks oli ka viht. Seda tõestavad näiteks Ratva (Jõhvi khk) keskaegsest külakalmistust leitud vihtade jäänused kolpade all (Lavi 1974: 24).

Surnupesijateks kutsuti enamasti naabrid. Lahkunu perekonnaliikmetele peeti pesemist liiga otsese kontakti tõttu laibaga lausa ohtlikuks (Iisaku, Vaivara, 1980). Reeglina pesi naissurnut naine ja meessurnut mees. Et pesija ei saaks lahkunult haigust külge, tuli talle tasuks annetada üht-teist surnu riietest.

Kui koolja sai pestud, hakati teda riietama. Suririided olid juba eluajal valmis vaadatud.

Surisärgi õmblemise juures ei tohtinud unustada, et selles ei tohtinud olla ei ühtegi sõlme ega ainustki nööpi, need tulivad äparduseks teises ilmas... (KV 90, 533 < Jõhvi khk Reet Viljand (1961)).

August Wilhelm Hupeli vahendusel on teada, et laibad mässiti valge linase riide sisse, vaestele pandi selga ainult särk, naistele veel põll ette (Hupel 1777: 155). O. Looritsa arvates asendus valge surirõivas mustaga eelkõige saksa mõjudel (Loorits 1949: 74). Kahjuks puuduvad uuritavast piirkonnast andmed varasema suririietuse kohta. Vanim notiits pärineb Jõhvi kihelkonnast alles 1939. aastast:

Vanal ajal pandi surnele selga vatlased riided ja villased sukad ja müts pähä (ERA II 268, 576 (44) < Jõhvi khk, Kohtla v, Kohtla k, Metsa t - Endel Mets < Salme Mets, s 1894 (1939)). 


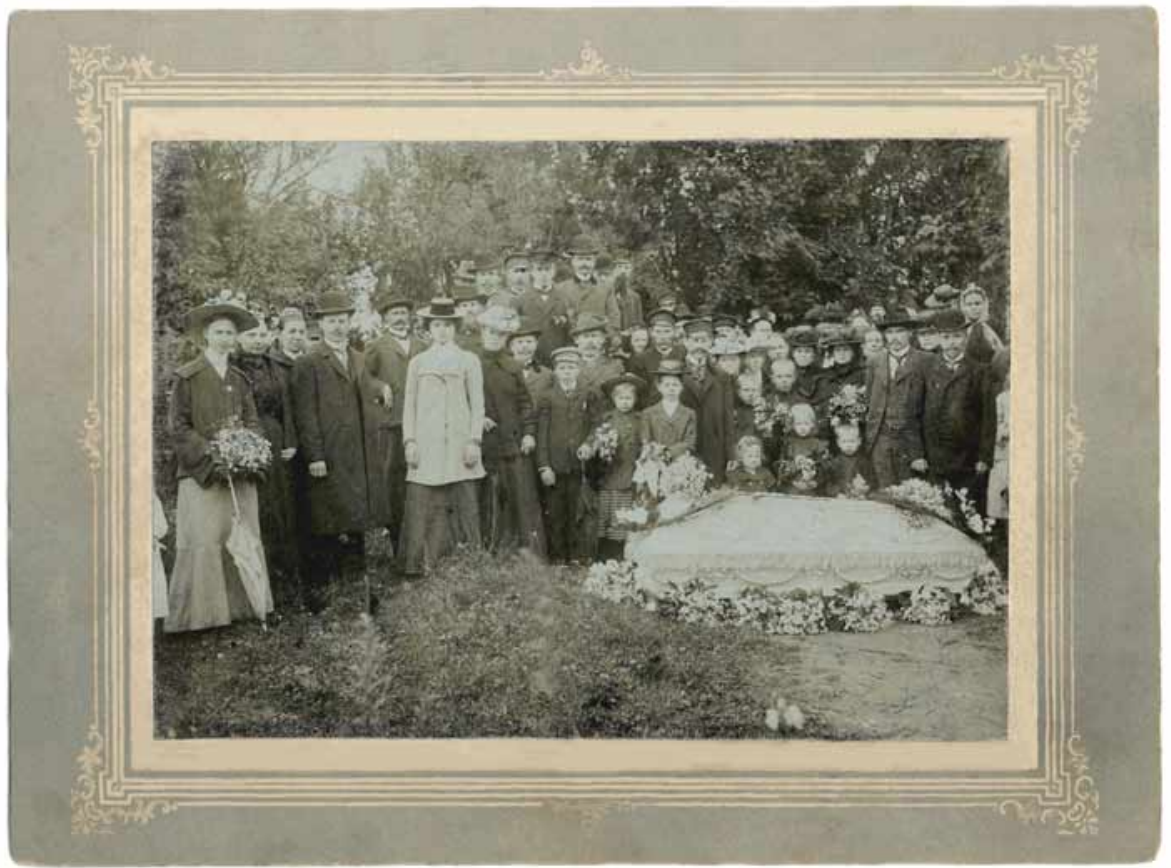

Foto 1. Matused 19.-20. sajandi vahetusel. Aeg ja koht teadmata. Virumaa Muuseumi fotokogu 1562:12.

Riietuse värvusele ei viidata. Ilmselt maeti sajandivahetusel valges vaid noori inimesi. Vadjas seevastu on valge surirõivas üldlevinud (Ariste 1974: 152, 155, 161).

Tavaliselt riietati naissurnu villasesse aluskuube või valgesse linasesse särki, mille peale käis kleit. Jalga pandi villased sukad ja riidest sussid. Abielunaisele pandi pähe tanu ja selle peale seoti rätik. Vallaliselt surnud võisid jääda palja peaga. Meessurnu sai selga linase särgi, aluspüksid, vesti, pintsaku, pikad püksid, kaela rätiku, jalga villased sukad, pähe mütsi. Laste surirõivaks oli kas ristimisriietus või õmmeldi eraldi valge kuub. Jällegi sukad jalga ja müts pähe.

Esitatud loetelust nähtub, et suririietus ei kujutanud endast midagi erilist ja kindlate nõuetega rituaalset rõivastust, vaid oli üsna tagasihoidlik. Muinasaegne eheterohkus ja pidulikkus olid täielikult kadunud. 


\section{Surnu kodus enne matmist}

Pärast surnu pesemist ja riietamist tuli teda veel kodus hoida enne kolme päeva ei tohtinud matta. Siiski viitavad vanemad allikad ka kiiremale matuste läbiviimisele. Nii näiteks kirjutas David Dubberch seoses 1586. aasta Karuse kirikuvisitatsiooniga, et kooljat võib matta siis, kui surmast on möödunud vähemalt 24 tundi (Winkler 1909: 17). Johann Wilhelm Ludwig von Luce täheldas Saaremaalt:

Matustega rutati 50 aasta eest veel niisama kui juudid teevad, ja kes hommikul surnud, puhkas tihti öhtul juba surnuaial (Luce 1827: 101-102).

Samasugust kiirustamist kohtas Fjodor Tumanski 18. sajandi lõpul vadjalaste juures (Öpik 1970: 113).

Selliste näidete puhul tuleb kindlasti arvestada mitmeid tegureid, mis võimaldasid nii kiiret tegutsemist (suremisaeg, puusärgi olemasolu jne). Samas kerkib aga küsimus, millistest riituse elementidest sel puhul matusekombestik üldse koosnes. Lühenes ju sellega surnu kodusoleku aeg, ära jäi pikk valvamisperiood. Võib-olla asendas seda lahkunuga mingis teises vormis suhtlemine, sest arvatavasti on "uueks eluks" ettevalmistav etapp olnud siiski vajalik. Paljud rahvad on suhtlemiseks kasutanud itku. Näiteks läänemeresoomlastel on seda jäädvustatud karjala, vepsa, ingeri, soome, isuri, vadja ja eesti aladelt (Pino \& Sarv 1981: 4). Itk oli omamoodi kontakti otsimine teispoolse maailmaga. Surnuitku abil püüti kooljat häälestada elavatele heasoovlikuks (Pino \& Sarv 1981: 22). Karjalased näiteks teatasid itkudes varem surnutele uustulnuka saabumisest ning tema kaudu anti esivanematele edasi sõnumeid ka elavate käekäigust (Duhhovnaja Kultura 1980: 25). Kuigi praegu piirdub Eesti alal itkude leviala setude asustuspiirkonnaga, on arvatud, et see võis kunagi olla ülemaalinegi (Tampere 1960: 209).

Kuni kirstupanekuni hoiti surnut külmas ruumis lautsil (laudil).

Laudi tegi surnele iga pere. Pandi kaks kotti kummagi otsa alla ja laud päälä ja ôligi laudi valmis (ERA II 268, 575 (41) < Jõhvi khk, Kohtla v, Kohtla k, Metsa t - Endel Mets < Salme Mets, s 1894 (1939)). 


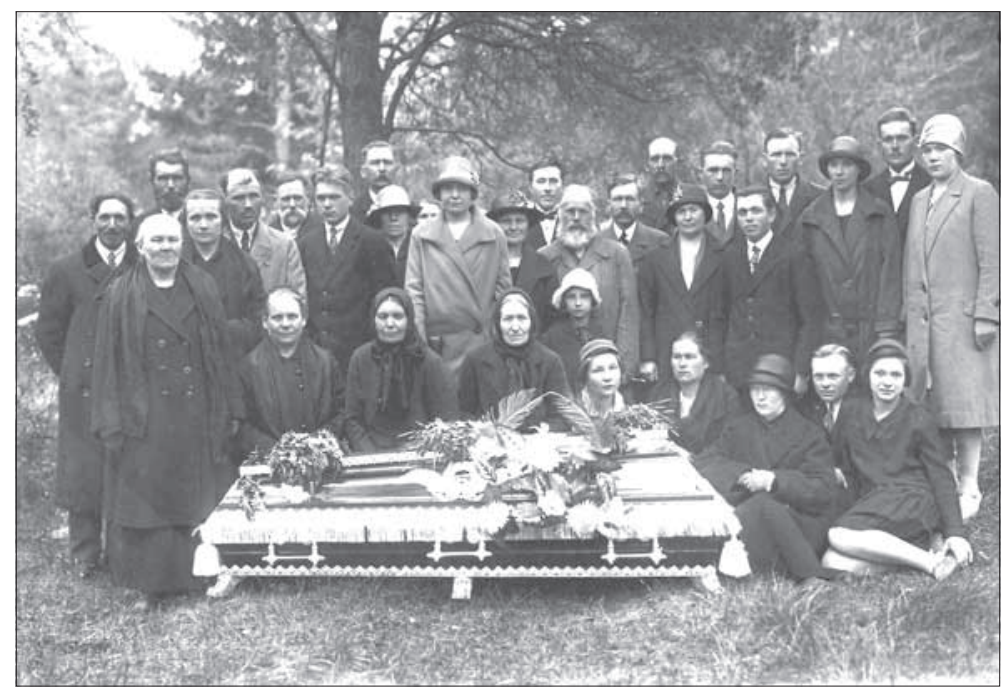

Foto 2. Matused 1926. või 1927. aastal. Toomikase foto. Virumaa Muuseumi fotokogu 1588:17.

Vahel pandi laudadele veel õlgkott ja kaeti valge linaga (KT 80, 67/ $8<$ Jõhvi khk (1944)). Lautsi asemel on kasutatud ka lihtsalt kahte pinki, millele tõmmati valge lina peale ja peaaluseks pandi väike kaselehtedega täidetud padi. Surnu asetati sinna selili, käed rinnal risti. Laip kaeti valge lina või kalinguriga.

Surnu lautsile jätmisega algasid omad mured. Kardeti, et enne matmist võib vanakuri valveta jäänud laiba ära viia või selle sisse pugeda. Samuti usuti, et kui surnu majasoleku ajal magada, siis võib koolja hing magaja hinge endaga kaasa viia. Niisuguste õnnetuste vältimiseks tuli öösiti ärkvel olla ja valvata, kusjuures kaitseabinõuna pidi tuli valgest valgeni põlema. Arvatavasti on 19. sajandil toimunud valvamisi igal ööl, hiljem aga ainult matusepäeva eelõhtul. Komme on hääbunud alates 1940. aastaist (Iisa$\mathrm{ku}, 1980$ ).

Valvamas käisid nii vanad kui noored (olenevalt lahkunu east). Valvajatele keedeti söögiks soolaherneid.

Õhta kogoti kokko, lauldi lauluraamatu laule ja perast akati tõisi laule laulma ja mängusid mängima. Mängiti tipi-täpi, numbri, omapaariga rahul ja nalja tehti igasugust (ERA II 


\section{Merike Lang}

166, 207 (8) < Jõhvi khk, Järve v, Saka k < Jõhvi khk, Jõhvi al - Armilda Hallik < Elisabet Suuban, s 1863 (1937)).

Kui kummaline selline rõõmsameelne käitumine antud situatsioonis ka ei tunduks, on siiski veel kolm samasisulist teksti Jõhvi kihelkonnast (1939., 1940. ja 1959. aastast) ning üks Narvast (1974. aastast). Oskar Loorits pidas lõbustusi ja naljalaule vanemaks kombeks, leinalaulude laulmine olevat uuem tava (Loorits 1949: 76). Rõõmsaid valvamisi tunti ka vepslaste, lõunakarjalaste (Pimenov 1960: 39; Duhhovnaja kultura 1980: 29), slaavlaste ja sakslaste matusekommetes (Gussev 1974: 54). Traditsiooni põhjenduseks olevat usk, mille kohaselt surnu osalevat neis lõbustustes ja minevat seega kergema südamega teise ilma (Gussev 1974: 55).

Surnu lautsil oleku ajal hangiti puusärk. Arheoloogia andmetel oli kirstus matmine Eestis tuntud juba nooremal rauaajal, kuid üldlevinuks muutus see alles keskajal, mida tunnistavad rohked kirstunaelte leiud 16.-17. sajandi külakalmetest (Lavi 1974: 63-64; 1975: 25). Edela-Soome laibamatustega kalmetest on andmeid kirstus matmisest (kirstunaeltest) juba 1. aastatuhande teisest poolest (Lehtosalo-Hilander 1982: 27-32). Võimalik, et puusärgi asemel on surnuid maetud lautsiga. Näiteks Kaberla külakalmest (Jõelähtme khk) on lauajäänuseid leitud peaasjalikult luustike alt (Selirand 1974: 75-76). Edela-Soome (Luistari) ning Kesk-Rootsi (Birka) viikingiaja haudadest leiti jälgi surnuraamidest, mis kujutasid endast kahe jämeda teiba vahele tõmmatud nahast või riidest kanderaami, millega surnu toodi matusekohta ja ka maeti (Lehtosalo-Hilander 1982: 33). Elisabet Richteri arvates võidi ainult lautsiga piirduda juba 1. aastatuhande teisel poolel, mil see põletati koos surnuga (Richter 1982: 96). Vanimat tüüpi kirstuks on aga arvatavasti olnud ühest puust õonestatud künakirst, mille kohta on Kirde-Eestist säilinud üsna palju andmeid.

Puusärki ei tehtud laudadest. Toodi metsast suur tugev pakk... Pakk tehti pooleks, õonestati seest ära, pandi surnu sisse, vits ümber ka et seisaks (KKI 20, 140 (20) < Iisaku khk, kolhoos Tee Kommunismile - Loreida Raudsep, Helgi Kihno < Johannes Karlep, 70 a (1955)).

Kahjuks ei tule ühestki tekstist välja, mis ajal taolisi künakirste kasutati. Ants Viires arvab, et 19. sajandi teisel poolel olid nad Eestis väga haruldased ning laudkirstud olid üldiselt kasutusel juba 
19. sajandi algupoolel, võib-olla veelgi varem (Viires 1960: 89). Laudadest puusärgid tehti

[---] kuuest lauast, ôtsalauad siis viel pääläkauba. Siis üävällaastud pandi põhja, mis tulivad, neist saigi ase... siis valge lina pandi siis laastude päälä. Piatsipatja siis pandi kaeraõled (KT 80, 70/1 < Jõhvi khk (1944)).

Kirstupanek toimus kas matusepäeva eelõhtul (arvatavasti vanem komme) või veelgi varem. Puusärgi sisseõnnistamiseks ja ametliku talituse läbiviimiseks kutsuti kohale kirikuõpetaja. Üldjoontes sarnanes see õhtu eespool kirjeldatud surnuvalvamisõhtutele (kohati võis see ka ainus valvamise aeg olla).

Kirstupanekul pandi tähele koolja seisundit, et selle järgi omaste saatust ennustada. Kui surnd kirstu tõstades nõrk oli, siis usuti, et liigidal naabriperedes varsti surma saab õlema (H II 37, 181 (4) < Jõhvi khk, Toila v, Päite k - Paulus Paurmann (1892)). Kui laiba parem jalg või käsi oli nõrgem ehk parem jalg pikem, võis varsti meesterahva surma oodata; pahem jalg või käsi tähendas naisterahva surma.

Veel 19. sajandil oli säilinud muistne komme panna kirstu mitmesuguseid esemeid. Oskar Loorits põhjendas seda kahelt maailmavaateliselt seisukohalt: 1) püsis vana soomeugriline arusaam koolja elu jätkumisest kuskil elavate läheduses ja seal vajas ta esemeid eelnevast elust; 2) lisandus indogermaani uskumuslikke elemente, kus peatähelepanu pöörati reisimisele teise ilma ning panused olid tarvilikud just sellel teekonnal (Loorits 1949: 111). Rahvatraditsioon aga seletas, et kui lahkunule midagi kaasa ei antud, hakkas ta koju käima ja oma omandit taga nõudma.

Üheks enamlevinuks ning veel 20. sajandil tuntud anniks oli raha (nn teeraha). Keskaegsetes külakalmetes leidus müntide kõrval üsna sageli (veel 18. sajandil) nii meestel kui ka naistel nuga (Lavi 1974: 73-74; 1975: 26). Kirjalikud allikad seda enam ei maini. Üsna sagedaste panustena esinesid tubakakott, piip, palveraamat, viinameestel viinapudel. Ehete kaasapanekut ei ole nimetatud. Laulatussõrmus võidi ära võtta või kaasa anda, kõrvarõngaste kohta aga öeldi:

Kes kõrvarõnnastega maetakse, sie pannasse põrgus rõnnastest lakke rippuma (ERA II 292, 202/8 (230) < Jõhvi khk, Kohtla v, Kohtla k, Metsa t - Endel Mets < Salme Mets, s 1894 (1940)). 


\section{Merike Lang}

Ehete osatähtsus panustena hakkas vähenema juba keskajal. 18.19. sajandi matuste leiuaineses on püsinud veel pronksist vits- ja südamekujulised sõled, helmed ja tinaehted (Lavi 1974: 73; 1975: 26).

Surnu kodusoleku ajal püüti võimalikult vaikselt olla, sest tema hing, mis veel maa peal viibivat, tahtvat rahu saada. Vanemates allikates öeldakse, et kui kuskil peres oli surnu, siis ei tohtinud terve küla töötada (Wiedemann 1876: 309; Vulfson 1908: 61; Grünthal 1912: 34). Uuritavast piirkonnast aga vastavad andmed puuduvad. Ilmselt on tegemist küllalt ammu ununenud tavaga.

Soojal ajal kippus surnu kergesti halvaks minema, samuti ei mõjunud hästi müristamine.

Kui surnu müristamise aal toas on, siis pandagu puusärgi alla üks viega täidetud riist, siis surnu ei lähe mitte haisema (H II 37, 656 (44) < Jõhvi khk - Tõnu Viedemann (1892)).

Kui müristas, siis pandi mättäd ümbär puusärki ja surne puusärgi kaanele lauluraamat ja raamatu päälä lamp põlema, siis surrud ei mend sinisest (ERA II 268, 576 (45) < Jõhvi khk, Kohtla v, Kohtla k, Metsa t - Endel Mets < Salme Mets, s 1894 (1939)).

Üheks mooduseks oli ka laiba kõrvale terariista asetamine (ERA II 37, 407 (9) < Jõhvi khk, Voka v, Konju k < Jõhvi khk, Mäetaguse v, Pagari k - Rudolf Põldmäe < Joosep Karukäpp, 83 a (1931)).

Nimetatud esemeid on usutud koolja puutumatuse hoidjateks. Laiba lehas nähti seda jõudu, mis surmas keha ja mis võis ka teistele hukku kaasa tuua. Usuti, et surma võim ulatus niikaugele, kui surnu lehk (Loorits 1949: 70).

\section{Surnu ärasaatmine}

Koolja ärasaatmise päev kujunes kogu kombestiku tähtsamaks ja rahvarohkemaks. Peale sugulaste osales matustel kogu küla. Erandiks olid surnud vallavaesed, keda läks matma ainult neli meest (KT 177, 22 - Jõhvi khk (1959)).

Matustele oli kombeks võtta kotiga mingit toidupoolist kaasa. Kirde-Eestist on teada ainult üks sellele viitav notiits, kus öeldakse, et võeti sepikut, liha või muud võimaluste piires (KT 80, 75/6 - 


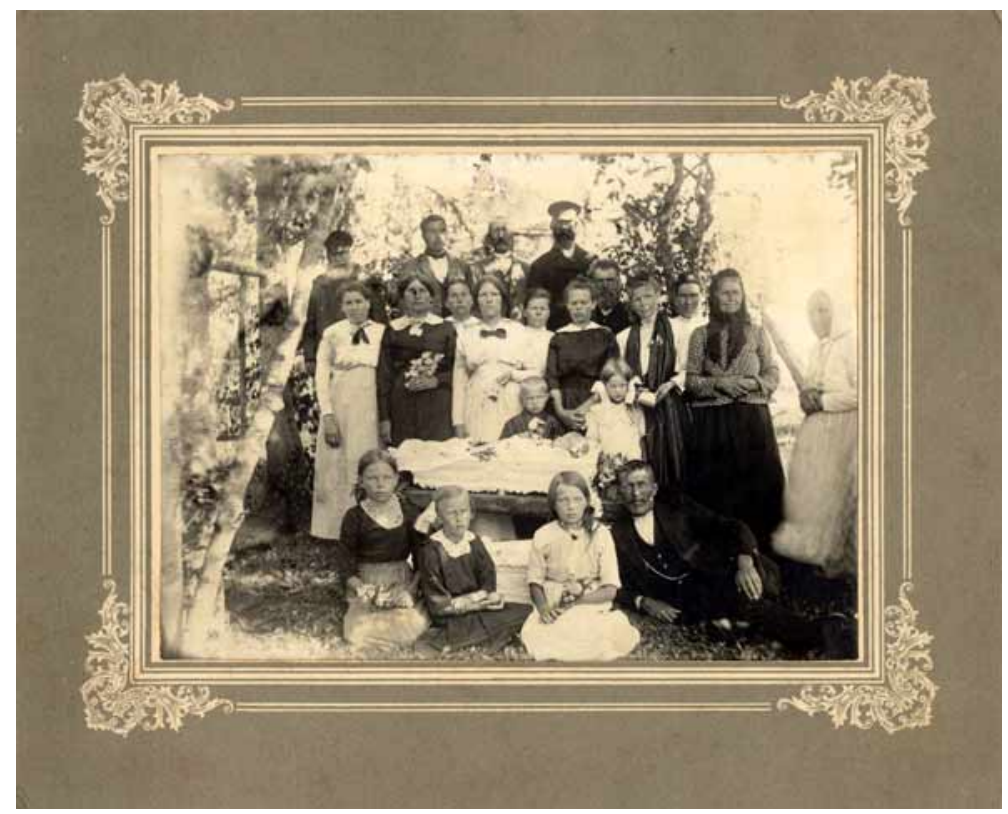

Foto 3. Lapse matused 1920. aastate alguses. Virumaa Muuseumi fotokogu 1458:36.

Jõhvi khk (1944)). Teise maailmasõja järgsed allikad ei räägi sellest tavast aga enam midagi. Samas on näiteks Võrumaal peiekoti kaasavõtmine olnud väga levinud komme (Lang 1981: 49-50). Selline tava on tuntud ka Soomes (Vuorela 1977: 623). Ilmselt on see komme 20. sajandil taandunud. Traditsioon võis aga kunagi olla seotud meie külaühiskonnas levinud vastastikuse abistamise kombega.

Kohati pakuti enne surnu väljasaatmist matuselistele söögiks sülti, kartuleid, saia, kohvi ja viina. Kuna vastav matusetoite puudutav materjal on kogutud valdavalt 1959. ja 1960. aastal, ei ulatu mälestused kuigi kaugesse aega ning seega ei saa otsustada kombe vanuse ja iseloomu üle. Võib oletada, et kohati kujunes sööming omamoodi rituaalseks toiminguks. Sellele viitavad Iisaku kihelkonnast pärinevad teated:

Kui surnu kodust ära viijasse, siis on herned sualaga ära kiedetud, ja kui laul, kellega surnut kodust välja saadetasse, lõp- 


\section{Merike Lang}

petatud on, siis pannase herned kausidega puusärgi piale ja saia ehk saia- vai pü̈̈likuagid, antasse saatjatele viina ja igaüks käib võttab puusärgi pialt herneid ja kuaki (H II 7, 786 (111) < Iisaku khk, Lemmaku < Iisaku khk, Kuru k < Iisaku khk, Sälliku k - Dietrich Timotheus (1889)).

Samasisulisi andmeid sisaldasid veel kolm notiitsi (KKI 20, 552/3 (39) - (1955); KKI 20, 619 (227) - (1955): KKI MT 272, 134/5 - (1961)) ja samuti teadis sellest rääkida A. Vetekaja Iisaku kihelkonna Sälliku külast. Sealjuures ta eelnevat toas söömist ei maininud (Iisa$\mathrm{ku}, 1980$ ). Vadja tekstides nimetatakse söömist esimest korda alles surnuaial (Ariste 1974: 152-182).

Puusärk viidi toast välja laulu saatel. Kandmisel hoiti surnu jalad ees, sest pea ees viimisel võis koolja jätta kodutee meelde ja hakata kummitamas käima. Kui aga hobused ei tahtnud vankrile asetatud kirstu vedama hakata, tuli see tuppa tagasi viia ja lahkunu pea ees välja kanda (ERA II 268, 579 (1) < Jõhvi khk, Jõhvi v, Sompa k Endel Mets < Gustav Lasberg, 68a (1939)).

Et takistada kodukäimist, löödi lävepakku suur raudnael, terav ots surnule järele (H II 8, 114 (11) < Jõhvi khk, Toila v, Päite k Paulus Paurmann (1889); E 268 (2) < Jõhvi khk - J. Seland (1893)). Nimetatud tõrjemaagilist võtet kirjeldasid juba mitmed vanema põlve autorid (Boecler \& Kreutzwald 1854: 69; Hupel 1777: 156; Scherwinzky 1788: 64; Wiedemann 1876: 310; Waronen 1898: $94-$ 95; Vulfson 1908: 63; Eisen 1920: 165) ning peale Eesti on see olnud tuntud ka karjalastel (Duhhovnaja kultura 1980: 20). Liivlased tegid lisaks naelale vasaku jala kannaga lävele ristimärgi (Loorits 1932b: 190). Soomlased, laplased ja lätlased lõid aga naela sellele kohale, kus oli seisnud kirst (Waronen 1898: 92-96). Meil esineb seda valdavalt Lääne-Eestis (Raadla 1939: 41).

Muistse kombe kohaselt tuli surnu heaks ohverdada mõni koduloom. 19. sajandiks on aga otsene ohvritalitlus enamasti unustatud (Viluoja 1971: 37-38). Konkreetsesse matusetseremooniasse kuuluva ohverdamisena on Kirde-Eestist teada vaid üks tekst kuke tapmisest uksekünnisel (ERA II 268, 579 (2) < Jõhvi khk, Jõhvi v, Sompa k - Endel Mets < Gustav Lasberg, 68 a (1939)). Küll mäletatakse aga kohati veel tänapäevalgi, et matusteks tuli kindlasti mõni suurem loom ära veristada (Iisaku, 1980). Sellist ohverdamist võib arvata kaudseks, kuna ta ei olnud matusekommetes seotud konk- 
reetse ajahetkega. Kombe põhjenduseks on toodud, et muidu ei saavat surnu hing rahu ja hakkavat käima endale karja välja valimas. Nii võis tervest laudatäiest loomadest ilma jääda (E 8730/1 (6) < Jõhvi khk - J. Seland (1893); ERA II 177, 206 (7) < Jõhvi khk, Kohtla v, Kohtla k, Metsa t - Endel Mets < Salme Mets, s 1894 (1937/8)). Isegi last ei tohtinud väiksemast loomaohvrist ilma jätta. Mida vanem ja tähtsam inimene oli olnud, seda suuremat andi ta nõudis.

Kuna iga uus surmajuhtum oli kardetud sündmus, pandi matustel tähele igasuguseid märke, et selle järgi tulevikku ennustada. Näiteks kui kooljat välja saates kuskil kukk kires või koerad vingusid, pidi varsti jälle surnuid saama (H III 1, 264 (1) < Jõhvi khk, Kohtla v, Kukruse k - Dietrich Timotheus (1888); H II 8, 54 (2) < Jõhvi khk, Toila v, Päite k - Paulus Paurmann (1889); E 268 (4) < Jõhvi khk J. Seland (1893); E 7793a (53) < Vaivara khk, Repniku m - Aleksander K. Feldbach (1893); ERA II 125, 242 (9) < Iisaku khk, Illuka v, Imato k, Sarika t - Mart Tarum < Liina Kinn, 76 a (1936); ERA II 166, 31 (100) < Iisaku khk, Illuka v, Kaidma k, Sommeri t < Iisaku khk, Iisaku v, Varesmetsa k - Armilda Hallik < Kai Hallikas, s 1862 (1937)).

Kui hobune surnu äraviimise juures pea longu ajab, siis saab sealt samast perest surnud (E 7793a (52) < Vaivara khk, Repniku m - Aleksander K. Feldbach (1893)).

Kui surnu kandmise juures hobune toa ees sittub, saab sealtsamast surnud (E 7793a (50) < Vaivara khk, Repniku m - Aleksander K. Feldbach (1893)).

Kirst asetati vankrile nii, et sõites oleksid lahkunu jalad eespool. Surnuvanker pidi matuserongis kõige ees sõitma, seda juhtis keegi meessugulane.

Kõik matuselised ei pidanud surnuaeda kaasa minema, osa võis jääda koju süüa tegema ja tube koristama. Et lõpetada täielikult koolja kontaktid koduga, oli vaja kohe põrandaid pühkida. Prahti ei soovitatud ahju visata, vaid see lennutati värava taga nelja tuule suunas laiali. Seejärel tehti kohale, kus puusärk oli seisnud, sibulakoortest, nõmmeliivateest ja kuuseokstest tuli, et saaks surnu lehagi toast välja (KT 80, 81 < Jõhvi khk (1944)). Peale selle soovitati õues sealt kohast pühkida, kust kadunuke oli üle viidud (E 269 (10) < Jõhvi khk - J. Seland (1893)). 


\section{Merike Lang}

Matuserongis loeti halvaks märgiks seda, kui tuul puhus tagant, sest siis võtvat surnu maja vara endaga kaasa (ERA II 166, 31 (101) < Iisaku khk, Illuka v, Kaidma k, Sommeri t < Iisaku khk, Iisaku v, Varesmetsa k - Armilda Hallik < Kai Hallikas, s 1862 (1937)). Sama tähendas ka hoburakendi katkemine (ERA II 268, 580 (6) < Jõhvi khk, Jõhvi v, Sompa k - Endel Mets < Gustav Lasberg, 68 a (1939)). Ebameeldivaks endeks olid surnurongile vastutulijad või risti üle tee minejad, sest nende kaudu võis surm oma mõju maha jätta ja nii oli varsti jälle matuseid oodata.

Et koolja koduteed meelde ei jätaks, oli vaja teda eksitada:

Kui surnu kotund kiriku viidi, siis pidi tee peal surnuga kolm korda ratast moodi risti sõitma. Siis ei hakanud enam kotu käima (E 8729 (3) < Jõhvi khk - J. Seland (1893)).

Üheks eriti Võrumaal veel tänaseni mäletatud ja kasutatud kodukäija tõkestamise vahendiks on teeäärse puu sisse ristimärgi lõikamine (Lang 1981: 61-64). Algselt võis sellel surnu mälestuse jäädvustamise ja sealjuures surnule mingi ohvri toomise tagamõte olla. Matti Waronen täheldas vanadel soomlastel surnu mälestuseks ühe puu laasimist (Waronen 1898: 97-101). Kahjuks on Kirde-Eestist ristipuude kohta teada vaid üks notiits:

Kui surnut matma mennase ja tie pial hobune kusele hakkab, et seisma jääb, ehk kui hobune seisma ei jääi, siis pietasse hobune ühes kõhas kinni, leigatasse ühe puu sisse rist ja üeldasse: Seiasaadik tohid tulla ja mitte kaugemalle... (H II 7, 783/4 (104) < Iisaku khk, Tudulinna k - Dietrich Timotheus (1889)).

Tekstist nähtub, et maagilist toimingut võis täiendada veel ka sõnamaagia. Praeguseks on ristide puudesse lõikamise komme uuritavas piirkonnas täiesti ununenud. Ei teata isegi nimetada kohti, kus vanu ristipuid võiks veel kohata (Vaivara, Iisaku, 1980).

\section{Matmine ja peied}

Kiriklike matuste puhul kanti surnu kõigepealt kirikusse. Kandmisel hoiti ikka jalad eespool, alles kohale jõutud, keerati pea altari poole. Puusärki kanti pikkadel linastel rätikutel. Arvati, et matusteks löövaid kirikukelli lahkunu veel kuuleb ning seetõttu ni- 
metati neid hingekelladeks (ERA II 268, 569 (14) < Jõhvi khk, Kohtla v, Kohtla k, Metsa t - Endel Mets < Salme Mets, s 1894 (1939)).

Haua kaevasid omaksed kas eelmisel päeval või matusepäeva hommikul. Hauakaevajatele pidi töö eest kindlasti mingit tasu andma, sest muidu võisid nad haigeks jääda.

Haua juures avati kirstu kaas, et kontrollida, kas surnu pole teel külili põrunud. Kui viga jäi parandamata, siis võis koolja hakata koju käima ning sel juhul ei aidanud muu, kui haud uuesti lahti kaevata ja laip õigesse asendisse keerata (H II 37, $151<$ Vaivara khk - Hermann Hendel (1892)).

Kogu matusetalitlus toimus kirikuõpetaja juhtimisel vastavalt ametlikule riitusele. Ometi ei unustatud sinna sisse põimida rahvauskumuslikke maagilisi taigu.

Kui surnu sai maha maetud, pidi pahema jala kannaga kolm korda kääpa äärele vajutama, et sellega koolja lõplikult hauda kinnistada (E 269 (6) < Jõhvi khk - J. Seland (1893)). Sama tõrjemaagiline võte oli tuntud ka liivlastel (Loorits 1932b: 195). Lahkunu peaotsiku kohale pandi rist, millele tehti alla otsa auk sisse ja sinna asetati 10, 15 või 20 kopikat (H II 7, 786 (112) < Iisaku khk, Lemmaku k < Iisaku khk, Kuru k < Iisaku khk, Sälliku k - Dietrich Timotheus (1889)). Nimetatud tava kinnitavad ka keskaegsetest külakalmistutest juhuleidudena haudade piirkonnast saadud mündid (Lavi 1974: 64-65).

Tõenäoliselt meie ajaarvamise algusest peale levis Eesti alal haual söömise komme. Tänapäeval on see säilinud vaid setudel ja lähematest naabritest vadjalastel, kusjuures kindlaks peietoiduks on kutja (Moora 1976: 87; Manninen 1924: 17; Ariste 1974: 153, 155, $172,174,177)$. Kutja retsept on järgmine: 1 toobi külma vee sisse klopitakse 1 nael mett ja lisatakse $1 / 2-1$ naela hautatud herneid juurde. Sellest seost saadakse vedel supp. Ongi valmis. Süüakse lusikaga (Manninen 1925: 17; kutja levikust vt Moora 1976: 85).

Kirde-Eestist kasutada olnud materjal viitab söömingule surnuaial kui juhuslikule ilmingule. Öeldi, et kui üldse midagi kaasa võe$\mathrm{ti}$, siis vaid kaugemalt tulnud sugulastele, kes kavatsesid kohe koju tagasi sõita (KV 103, 572 < Vaivara khk, Alutaguse v - August Martin (1959); KV 103, 496 < Iisaku khk, Mäetaguse v, Metsküla - Mall Proodel (1960); KV 104, 1078 < Iisaku khk, Iisaku v, Vaikla k, Liiva k, Kuru k - Alli Vetekaja (1962)), ning hauakaevajatele (KV 103, $572 / 3$ < Vaivara khk, Alutaguse v - August Martin (1959)). Kaasavõetavatest söökidest nimetati külma liha, leiba, saia ja pirukaid 


\section{Merike Lang}

(KV 103, 496 < Iisaku khk, Mäetaguse v, Metsküla - Mall Proodel (1960)). Ühe Jõhvi kihelkonnast pärineva notiitsi järgi pidavat sööming matuseaia juures üldse uuemaaegsem linnaelanike ja kaugelt surnuaiale tulnute komme olema (KV 104, 946 < Jõhvi khk Reet Viljand (1962)).

Kuna surnuaed oli elavatele siiski üsna ohtlik territoorium, püüti pärast matust sealt võimalikult kiiresti lahkuda. Kes jäi viimaseks tulema, pidi ka kõige enne surema (H III 1, 301 (21) < Jõhvi khk, Kohtla v, Võrnu k (1889); ERA II 199, 77 (8) < Jõhvi khk, Kohtla v, Kohtla k, Metsa t-Endel Mets < Salme Mets, s 1894 (1938); KT 80, $84<$ Jõhvi khk (1944)).

Kuigi surnu oli nüüd maha maetud, ei võinud veel kindel olla, kas ta ikka on oma uude keskkonda piisavalt kindlalt suletud. Võis juhtuda, et tagasiteel kihutas matuselistest keegi tundmatu mööda. Sellest arvati, et kindlasti on koolja neile järele saanud ja kodukäijast pole enam pääsu (KT 80, 82 < Jõhvi khk (1944)). Kui hobune lõi kodu õues pea maha, usuti sellest jällegi peatset surma (H II 7, 638 (13) < Jõhvi khk, Kohtla v, Kukruse k - Dietrich Timotheus (1889)).

Võimalike kooljalt saadud kahjustuste vältimiseks pidid kõik peielised matusemajja saabudes käed vastu ahju panema (H II 8, 118 (24) < Jõhvi khk, Toila v, Päite k - Paulus Paurmann (1889); H II 7, 910 (7) < Vaivara khk - August Tõnurist (1890)) või pesema (H II 8, 118 (25) < Jõhvi khk, Toila v, Päite k - Paulus Paurmann (1889); ERA II 268, 581 (11) < Jõhvi khk, Jõhvi v, Sompa k - Endel Mets < Gustav Lasberg, 68 a (1939); H III 31, 486 < Narva l - Miina Russmann (1905)).

Matused lõppesid peietega, mida peeti tavaliselt õhtul lahkunu kodus. Sööming toimus kõigile kutsututele korraga. Ainult E. Ranniste (sünd 1907) endisest Iisaku kihelkonna Raasiku külast teadis rääkida, et söömine olevat olnud kahes jaos, s.t enne lähedastele sugulastele ning seejärel teistele. Seda kommet ei põhjendanud ta ruumikitsikusega, vaid nimetas üldiseks tavaks. Siiski ei kinnitanud teised külas küsitletud seda traditsiooni (Iisaku, 1980). Kahes jaos sööming on tuntud ka vadjalastel (Ariste 1974: 153-154).

Käsitletava piirkonna peietoite puudutav käsikirjaline materjal ei võimalda meil nii notiitside nappuse kui ka oma kaasaegsema sisu tõttu saada täielikku ülevaadet vanemast matusetoidust. Võib arvata, et kuna nn surnule ohverdamiseks oli vaja veristada loom, siis sellest lihast ka midagi valmistati. Nii näiteks võiks vanemaks 
traditsiooniks pidada lihasuppi (lihaga hernesupp, hapukapsasupp). Arvestades aastast toidujaotust võiks verivorste ja sülti pidada rohkem talvise peietoidu hulka kuuluvaks. Putrudest on matusetoiduks peetud tangu-, herne- ja riisiputru. Aliise Moora andmetel oli Kirde-Eestis (ka setudel, vadjalastel ja Peipsi-tagusel alal) lõputoiduks alati kaerakile (Moora 1976: 87).

Alates Eesti Vabariigist lisandusid soojadele toitudele mitmesugused külmad road, mida tunneb meie tänapäevanegi toidulaud (salatid, külmad lihalõigud, heeringas jms).

1909. aastal ilmus Prantsusmaal Arnold van Gennepi raamat Les rites de passage, mis pani kombestiku süsteemses uurimises aluse uuele, nn siirderituaalide teooriale. Hiljem on seda täiendanud mitmete maade teadlased (vt lähemalt Honko 1964: 116-142; Honko \& Pentikäinen 1970: 60-62).

Kujunenud süsteemi lähtekohaks on idee, et vastavalt inimese elus toimuvatele füsioloogilistele muutustele (sündimine, suguküpsuse saavutamine, abiellumine, suremine) toimuvad muutused ka isiku sotsiaalses seisundis, tema asendis ühiskonnas. Peamine on see, et staatuse vahetust ei loeta teostunuks mitte bioloogilise muutuse momendil (näiteks sünd või surm), vaid alles pärast vastavate siirderituaalide täitmist, millega rolli vahetav isik irrutatakse endisest seisundist (irrutamisriitus), valmistatakse ette uueks (vaheriitus) ning liidetakse sellega (liitmisriitus). Seega on tavandi toimimise tähtsaimaks eesmärgiks seatud sotsiaalse muutuse saavutamine. Eri sündmuste puhul jõutakse aga oodatava tulemuseni erinevalt, s.t nimetatud kolm siirderituaalide astet ei oma alati ühesugust kaalu ja järgnevust. Näiteks matusekommetes saab ülekaalu irrutamisstaadium, millele vastavad rituaalid läbivad vaheldumisi teistega kogu kombestiku.

Eelnevalt käsitletud matuste käigu võime tinglikult jagada nelja etappi. Jaotuse aluseks võtame sooritatavate taigade iseloomu, mis eeldab teatud suhteid elavate ja surnu vahel, ning riitusse haaratute sfääri laienemist.

Arvestades neid tingimusi võib endisaegseid matusekombeid hakata käsitlema juba alates haigusest ja hingevaakumisest. Kuigi faktiliselt pole veel tegemist surma kui tavandile bioloogilise algtõuke andjaga, on tema tulek teatud ennete järgi aimatav. Kui ilmnes, et kriitilisele olukorrale oli oodata ainult üht lahendust - surma - , mindi selle tuleku kiirendamise teele (põdeja õlgedele tõstmine, voodi hoidmine piki laepalke jms). Seega tuleb matusekom- 


\section{Merike Lang}

bestiku esimesel perioodil kõige selgemini esile sotsiaalse eesmärgi ülekaal bioloogilise faktori üle. Võib ju hingeheitmisel teostatavaid taigu pidada juba irrutamisrituaalideks. Sellega aga väljusid sündmused ühe perekonna raamest, toimunut pidid hakkama arvestama ka teised ümberkaudsed (suretamas käimine). Leiab aset otsekui kahepoolne häälestumine: 1) kujunes välja suretajate ettevaatlik-tähelepanelik hoiak suretatava suhtes, mis olukorra tõsinedes juhindus üha enam enesealalhoiutaotlusest; 2) põdeja meeleolu loomine eelseisvateks muutusteks, arvestades jällegi ellujääjatele kasulikke eesmärke.

Surm kui bioloogiline muutus alustab matuste teist perioodi, kuhu kuuluvad laiba pesemine, rõivastamine ja öine valvamine. Ilmneb, et kuigi irrutamisega on juba algust tehtud, käsitatakse surnut veel inimühiskonda kuuluva olendina, kes tuleb alles uueks seisundiks ette valmistada. Seega on meil tegemist vaherituaalidega, kuigi irrutamine on jäänud ikkagi päevakorrale.

Kõik teisel perioodil toimuv oli omamoodi suhtlemine surnuga, sest uskumuse kohaselt polnud see lihtsalt elutu kehaga ühepoolne ümberkäimine, vaid kogu tegevus omas vastastikku mõjuvat toimet. Koolja suhe elavaga oli enamasti seotud teatud ebameeldivate kõrvalmõjudega. Surnu liiga lähedane kontakt sugulastega kätkes endas kahjulikumaid tagajärgi kui võõrastega, kuid teatud nõudeid täites võis ohtlikkus kaduda. Viimane annab aluse võrrelda elavate suhet kooljaga üldistes joontes suhtlemisega uueks sotsiaalseks staatuseks veel ebaküpse isikuga, kelle tulevase seisundi kujundamine oli sõltuv tema lähikondlaste tegevusest. Järgides aga suulist rahvatraditsiooni kitsamas mõttes, nähtub, et kõikidel surnuga läbiviidavatel toimingutel oli siiski juures tugev hirm kurjade jõudude, kuradi ja kodukäijate ees. Eriti tuli taoline tendents ilmsiks matuste kolmandal perioodil - surnu kodust ärasaatmisel ja matmisel.

Nimetatud kolmandat perioodi võiks alustada laiba puusärgitamisest (juhul, kui see toimus matusepäeva eelõhtul). Kirstupanek ja esemete kaasaandmine oli veel ettevalmistus üleminekuks uude keskkonda, kuid see pani aluse ka järgnevatele liitmisrituaalidele.

Kõige tihedam tavandi osa algas surnu kodust ärasaatmisega. Ametliku kirikliku riituse kõrval ei unustatud rahvalikke tarkusi. Kõik see aitas lahkunut kinnistada teise maailma, kuid samal ajal irrutas teda senisest ümbruskonnast. Puhtad liitmisrituaalid tulevad kasutusele alles hauda laskmise järel. 


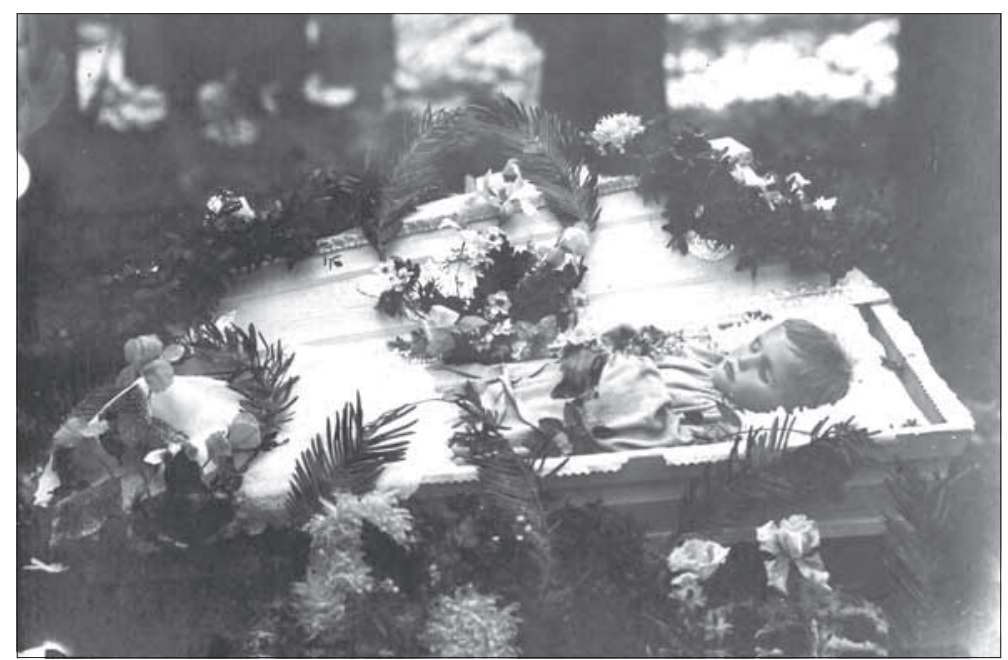

Foto 4. Gustav Vaarmanni matus. J. E. Maibachi foto. Virumaa Muuseumi fotokogu 1588:11.

Kolmandal perioodil on kombestikus osalejate hulk kasvanud maksimumi, kusjuures toimuvast on mõjustatud kõik matuselised. Seepärast torkab silma elavate tõrjuv suhtumine surnusse. Põhisuund on võetud sellele, et surnu ei hakkaks tagasi käima, et ta soovid saaksid rahuldatud. Selle taga on muidugi esivanemate kultuse jäänusena säilinud teatud austav hoiak kooljasse (ohverdamine).

Neljandasse perioodi kuuluvad ka peied, mis tähistavad surnu liitmist uue keskkonnaga, tema jõudmist uude sotsiaalsesse staatusse. Nüüdsest peab lahkunusse suhtumine olema ainult heatahtlik, on keelatud meenutada teda halva sõnaga.

Selline võis lühidalt olla matusekombestiku ideeline alus siirderiituse teooria põhjal. Arvestades aga eelnevalt käsitletud tegelikku kombestikku, võiks teooria kohta öelda järgmist. Kõigepealt, "puhtaid" riitusi (irrutamine, ettevalmistamine, liitmine) on vähe ning ülekaalus on mitmetähenduslikud taiad. Sealjuures on viimastes tugevamini esindatud just irrutamisriitus (irrutatakse selleks, et tugevamini liita, või vastupidi). See tendents võib olla tingitud asjaolust, et matusekommetes on sotsiaalse muutuse taotlus tugevalt seotud bioloogilise muutusega. Just surnu eriline füsioloogiline seisund annabki taigadele sellise tagapõhja. 


\section{Merike Lang}

Siirderiituse teooria kujutab endast üldmõistelist tavandianalüüsi, mis lähtub kogu kombetalituse sotsiaalsest lõppeesmärgist. Ent inimeste tegevuses pole see eesmärk kuigi selgepiiriliselt teadvustatud. Igal taval on rahvatraditsioonis palju kitsam sisuline põhjendus, mille järgi võib näiteks eristada puhastus- ja tõrjemaagilisi elemente, esivanemate kultust jms. Sageli on raske üht või teist taiga teooria kohaselt klassifitseerida.

Arnold van Gennepi teooria käsitleb kombestikku mingiks momendiks fikseerunud tasandilt, arvestamata ühe või teise elemendi maailmavaatelise kujunemise aega. Nagu juba artikli sissejuhatuses mainiti, koosneb kombestik siiski eri aegadel ladestunud usundilistest arusaamadest. (Rahvausundi ajaloolisest arengust vt lähemalt Loorits 1932b, 1932c, 1949; 1951-1953; 1957-1960; Paulson 1966.) Seega peaks tavandi uurimisel lähtuma eeskätt ajaloolisest aspektist. Nii võib tulla muutusi ka siirderituaalide klassifitseerimisel ühte või teise liiki. See eeldab aga sisuliselt palju sügavamat tööd, kui ainult ühte kitsast piirkonda haarav artikkel.

\section{0. aastal välitöödel hõlmatud külade loetelu (kihelkonnajaotuse järgi)}

Jõuga k, Iisaku v ja khk

Kauksi k, Iisaku v ja khk

Porskovo (praegu Vaikla) k, Iisaku v ja khk

Sälliku k, Iisaku v ja khk

Katerma k, Illuka v, Iisaku khk

Kuremäe k, Illuka v, Iisaku khk

Raasiku k (praegu Kuremäe k koosseisus), Illuka v, Iisaku khk

Lemmaku k, Tudulinna v, Iisaku khk

Tudulinna k ja v, Iisaku khk

Agusalu k, Vasknarva v, Vaivara khk

Utria k, Alutaguse v, Vaivara khk

\section{Kommentaarid}

${ }^{1}$ Artikkel on kirjutatud aastatel $1983-1984$ ja põhineb autori 1981. aastal valminud diplomitööl. Hiljem pole Merike Lang käesoleva teemaga enam tegelnud. Mäetaguste toimetus palus avaldamisluba, sest Ida-Eesti 
matusekombestikust pole muid eriuurimusi ja aastatetagusele diplomitööle viidatakse tänini.

${ }^{2}$ Praeguseks üle antud Eesti Kirjandusmuuseumile.

${ }^{3}$ Loetletud on üksnes spetsiaalselt matusekombeid käsitlevaid ülevaatlikke töid, mis olid valminud artikli kirjutamise ajaks.

\section{Käsikirjaarhiivid lühendid}

\section{Käsikirjalised rahvaluulekogud Eesti Kirjandusmuuseumi Eesti Rahvaluule Arhiivis}

E = M. J. Eiseni rahvaluulekogu (1880-1934 ja mõned varasemad tekstid)

EKS = Eesti Kirjameeste Seltsi rahvaluulekogu (1867-1891)

ERA = Eesti Rahvaluule Arhiivi rahvaluulekogu (põhiliselt 1927-1944)

ERM = Eesti Rahva Muuseumi rahvaluulekogu (1915-1925)

EStK = M. J. Eiseni stipendiaatide rahvaluulekogu 1921-1927

H = J. Hurda rahvaluulekogu (1860-1906)

KKI = Keele ja Kirjanduse Instituudi rahvaluule sektori rahvaluulekogu (1947-1980)

RKM = Eesti TA Fr. R. Kreutzwaldi nim (Riikliku) Kirjandusmuuseumi (nüüd Eesti Kirjandusmuuseumi) rahvaluule osakonna rahvaluulekogu (peamiselt alates 1945. aastast)

\section{Käsikirjalised murdekogud Eesti Keele Instituudis}

KKI MT = KKI (nüüd EKI) murdetekstid (1947-2001)

KT = Emakeele Seltsi murdekorrespondentide tekstid (1941-2000)

ÜS = KKI (nüüd EKI) murdesektori üldsõnavara kartoteek

\section{Eesti Rahva Muuseumi käsikirjalised teatmekogud}

$\mathrm{KV}=$ Kirjasaatjate vastused (alates 1931)

$\mathrm{EA}=$ Etnograafiline arhiiv (alates 1920) 


\section{Merike Lang}

\section{Kirjandus}

Ahven, Heino (koost) 1957. Pajatusi põhjarannikult: Kirde-Eesti rannikumurre. Valimik korrespondentide murdetekste 2. Tallinn: Eesti NSV Teaduste Akadeemia.

Allik, Eha 1970. Eesti surmaended. Diplomitöö. Käsikiri: Tartu Ülikooli kirjanduse ja rahvaluule kateeder.

Ariste, Paul 1974. Vadjalane kätkist kalmuni: [Vadja tavanditest]. Emakeele Seltsi toimetised 10. Tallinn: Eesti NSV Teaduste Akadeemia.

Boecler, Johann Wolfgang \& Kreutzwald, Friedrich Reinhold 1854. Der Ehsten abergläubische gebräuche, weisen und gewohnheiten. Sankt Petersburg: Buchdruckerei der Kaiserlichen Akademie der Wissenschaften.

Duhhovnaja kultura 1980 = Духовная культура сегозерских карел конца $X I X-$ начала $X X$ в. Ленинград: Наука.

Eisen, Matthias Johann 1920. Eesti uuem mütoloogia. Eesti mütoloogia 2. Tallinn: Rahvaülikool.

Grünthal, A. 1912. Surnute austus. Eesti Kirjandus, lk 342-348.

Gussev 1974 = Гусев, Виктор 1974. От обряда к народному театру: Эволюция святочных игр в покойника. Путилов, Борис (toim). Фольклор и этнография: Обряды и обрядовый фольклор. Ленинград: Наука, lk 49-59.

Honko, Lauri 1964. Siirtymäriitit. Sananjalka: Suomen kielen seuran vuosikirja 6. Turku: Suomen Kielen Seura, lk 116-142.

Honko, Lauri \& Pentikäinen, Juha 1970. Kulttuuriantropologia. PorvooHelsinki: WSOY.

Hupel, August Wilhelm 1777. Topographische Nachrichten von Lief- und Ehstland. 2. Riga: Johann Friedrich Hartknoch.

Jung, Jaan 1879. Eesti rahwa wanast usust, kombedest ja juttudest. Tartu: H. Laakmann.

Kreutzwald, Friedrich Reinhold 1953. Maailm ja mõnda. Karl Taev (koost ja toim). Teosed. Tallinn: Eesti Riiklik Kirjastus.

Lang, Merike 1981. Endisaegsed matusekombed Ida-Eestis. Diplomitöö. Käsikiri: Tartu Riikliku Ülikooli NSV Liidu ajaloo kateeder.

Lavi, Ain 1974. Külakalmete uurimisest Põhja-Eestis. Diplomitöö. Käsikiri: Tartu Riikliku Ülikooli NSV Liidu ajaloo kateeder.

Lavi, Ain 1975. Paganlike matmistraditsioonide püsimisest Eestis 13.-18. saj. Eesti NSV Riikliku Etnograafiamuuseumi XVII teaduslik konverents: 14.-15. aprill 1975. Tartu: Eesti Riiklik Etnograafiamuuseum, lk 25-26. 


\section{Merike Lang}

Lehtosalo-Hilander, Pirkko-Liisa 1982. Luistari I: The Graves. Suomen Muinaismuistoyhdistyksen Aikakauskirja = Finska Fornminnesföreningens Tidskrift 82: 1. Helsinki: Suomen Muinaismuistoyhdistys.

Loorits, Oskar 1932a. Die Geburt in der livischen Volksüberlieferung. Õpetatud Eesti Seltsi Toimetused 26. Tartu: Õpetatud Eesti Selts, lk 131-169.

Loorits, Oskar 1932b. Eesti rahvausundi maailmavaade. Elav Teadus. Eesti Kirjanduse Seltsi populaarteaduslik seeria 12. Tartu: Eesti Kirjanduse Selts.

Loorits, Oskar 1932c. Estnische Volksdichtung und Mythologie. Tartu: Akadeemiline Kooperatiiv.

Loorits, Oskar 1932d. Der Tod in der livischen Volksüberlieferung. Opetatud Eesti Seltsi Toimetused 26. Tartu: Õpetatud Eesti Selts, lk 170-200.

Loorits, Oskar 1949. Grundzüge des estnischen Volksglaubens 1. Skrifter Utgivna av Kungl. Gustav Adolfs Akademien för Folklivsforskning 18: 1. Uppsala \& Köpenhamn: Lundequistska Bokhandeln \& Munksgaard.

Loorits, Oskar 1951-1953. Grundzüge des estnischen Volksglaubens 2: 1-2. Skrifter Utgivna av Kungl. Gustav Adolfs Akademien för Folklivsforskning 18: 2. Uppsala \& Köpenhamn: Lundequistska Bokhandeln \& Munksgaard. Loorits, Oskar 1957-1960. Grundzüge des estnischen Volksglaubens 3: 1-2. Skrifter Utgivna av Kungl. Gustav Adolfs Akademien för Folklivsforskning 18: 3. Uppsala \& Köpenhamn: Lundequistska Bokhandeln \& Munksgaard.

Luce, Johann Wilhelm Ludwig von 1827. Wahrheit und Muthmassung: Beytrag zur ältesten Geschichte der Insel Oesel. Pernau: Gotthardt Marquardt.

Manninen, Ilmari 1924a. Rahvateaduslikud küsimuskavad III: Matmiskombed. Eesti Kirjandus 4, lk 173-176.

Manninen, Ilmari 1924b. Setude matusekommetest. Eesti Keel III, lk 10-19.

Moora, Aliise 1976. Tavandi- ja peotoitudest eesti külas. Etnograafiamuuseumi aastaraamat 29. Tallinn: Valgus, lk 47-100.

Paulson, Ivar 1966. Vana eesti rahvausk: usundiloolisi esseid. Stockholm: Vaba Eesti.

Pimenov 1960 = Пименов, Владимир. К вопросу о карельско-вепсских культурных связах. Советская Этнография 5, lk 30-41.

Pino, Veera \& Sarv, Vaike 1981. Setu surnuitkud 1. Ars musicae popularis 2. Tallinn: Eesti NSV Teaduste Akadeemia.

Raadla, Amanda 1939. Eesti matusekommete ülevaade. Seminaritöö. Tartu: Tartu Ülikool. Käsikiri Eesti Rahvaluule Arhiivis.

Reiman, Helmi 1915. Eestlaste matusekombed. Villem Reiman (toim). Eesti Kultura IV. "Postimehe" kirjakogu 1: Tartu, lk 123-163. 


\section{Merike Lang}

Richter 1982 = Rihter, Elisabet. Mõningaid arhailisi jooni setu matusekommetes. Jüri Linnus (koost \& toim). Läänemeresoomlaste etnokultuuri küsimusi. Tallinn: Valgus, lk 96-100.

Scherwinzky, Christian Friedrich 1788. Etwas über die Ehsten besonders über ihren Aberglauben. Leipzig.

Selirand, Jüri 1974. Eestlaste matmiskombed varafeodaalsete suhete tärkamise perioodil (11.-13. sajand): Ülevaade. Tallinn: Eesti Raamat.

Sirijos-Giraite, Danute 1971. Surnutekultuse ühiseid jooni eesti, liivi, läti ja leedu rahvaluules ning mütoloogias. Diplomitöö. Käsikiri: Tartu Riikliku Ülikooli NSVL ajaloo kateeder.

Tampere, Herbert 1960. Eesti rahvalaule viisidega 2. Tallinn: Eesti Riiklik Kirjastus.

Valk, Heiki 1983. Kagu-Eesti keskaegsed külakalmed. Diplomitöö. Käsikiri: Tartu Riikliku Ülikooli NSVL ajaloo kateeder.

Viires, Ants 1960. Eesti rahvapärane puutööndus: Ajalooline ülevaade. Tallinn: Eesti Riiklik Kirjastus.

Viluoja, Eha 1971. Surmakujutelmast eesti rahvauskumustes: Kodukäija tõrje. Diplomitöö. Käsikiri: Tartu Riikliku Ülikooli eesti kirjanduse ja rahvaluule kateeder.

Viluoja, Eha 1978. Sõnamaagia kodukäijatõrjes. Ülle Viks \& Valdek Pall (toim). Sõnast tekstini. Tallinn: Eesti NSV Teaduste Akadeemia.

Vulfson 1980 = Вульфсон, Э. С. Эсты, их жизнь и нравы. Где на Руси какой народ живет и чем промышляет. Москва: Панафидин.

Vuorela, Toivo 1977. Suomalainen kansankulttuuri. Helsinki: WSOY.

Waronen, Matti 1898. Vainajainpalvelus muinaisilla suomalaisilla. Suomalaisen Kirjallisuuden Seuran toimituksia 87. Helsinki: Suomalaisen Kirjallisuuden Seura.

Wiedemann, Ferdinand Johann 1876. Aus dem inneren und äusseren Leben der Ehsten: Der Akademie vorgelegt am 30. Sept. 1875. St.-Petersburg: Keiserliche Akademie der Wissenschaften.

Winkler, R. 1909. Der estländische Landkirchenvisitator David Dubberch und seine Zeit (1584-1603): Ein Beitrag zur estländischen Kirchengeschichte. Ritter- und Domkirche (zu Reval): Sylvester-Abend 1909. Reval: Mickwitz.

Öpik, Elina 1970. Vadjalastest ja isuritest XVIII sajandi lõpul: Etnograafia ja lingvistilisi materjale F. Tumanski Peterburi kubermangu kirjelduses. Tallinn: Valgus. 